\title{
The Case for Real Welfare Reform
}

\author{
The Honorable Donna E. Shalala
}

Donna E. Shalala, Health and Human Services secretary, received an honorary degree from The George Washington University in 1993. Dr. Shalala served as chancellor of the University of Wisconsin-Madison from 1988-1993, president of Hunter College at the City University of New York for eight years, and as assistant secretary of policy development and research at the Department of Housing and Urban Development during the Carter administration. Dr. Shalala is a leading scholar on the political economy of state and local governments, and has held tenured professorships at Columbia, CUNY, and the University of Wisconsin.

As the welfare debate continues in Congress and across America, there is one principle that everyone agrees upon: the status quo must go.

The statistical dimensions of this tragedy are well-documented. Today, about 200,000 teenagers under eighteen give birth each year. Fourteen million people-nine million of whom are children-participate in the Aid to Families with Dependent Children program (AFDC) at an annual cost of $\$ 22$ billion. And, there is a $\$ 34$ billion gap between child support payments that are paid and those that could be paid.

The Clinton administration is committed to crafting real solutions to these problems. From day one, we have worked to build a foundation of economic and personal security for all Americans, thereby preventing countless families from having to resort to welfare in the first place. We have enacted sound domestic policies that have created more than five million jobs since 1993, while also achieving the largest deficit reduction in American history. Since taking office, the president has fought for-and signed into law-critical initiatives like the Crime Act, the School-to-Work Act, the Family and Medical Leave Act, child care expansion, Head Start expansion, education reform, and-perhaps most important for low-income families-a $\$ 21$ billion expansion of the Earned Income Tax Credit (EITC). The president's historic expansion of the EITC helped lift two million working families and their children out of poverty, and was, in essence, a first step to welfare reform.

If there is one thing I have learned from the welfare reform debate so far, it is that the tragedy of public dependence cannot be viewed from an ivory tower. It must be viewed from the trenches.

Today, we have a president who has been there in the trenches, devoting more than fifteen years to this challenge. President Clinton has talked to hundreds of people on welfare. He has heard their views, and he knows that no one wants to change the systern more than they do.

As governor of Arkansas, he championed the last federal bipartisan welfare reform effort, which resulted in the landmark Family Support Act that President Reagan signed into law in 1988. And, as president, he has worked to fix our broken welfare system so that it helps, rather than penalizes, people who work hard and play by the rules.

The Clinton administration believes that, first and foremost, real welfare reform should be about moving people from welfare to work. It should be about a paycheck, not a welfare check. It should be about expanding economic opportunities, not displacing people who are currently in the workforce. And, it should be about protecting our children, not leaving them out in the cold and saying "Sink or swim!"

Unfortunately, on 24 March 1995, the House GOP passed a welfare bill that is so weak on work and so tough on children that we really should not call it "reform."

This bill is not about empowering people to move from welfare to work. It is about cutting at least $\$ 66$ billion from a range of programs that help low-income people buy food and clothing for their children.

An opportunity to fix our broken welfare system has been missed. But, as the issue continues to move through Congress, this is where we should be headed.

\section{First, the test of real welfare reform is whether it moves people from welfare to work.}

Work should be the cornerstone of welfare reform, yet the original work requirements in the Republicans' legislation 
were so weak that even fewer people would be expected to work than under current law. Then, after Democrats protested, the work requirements were strengthened-but in such a slipshod and haphazard manner that even the Congressional Budget Office criticized them as unworkable and thus unreal.

In fact, the House bill would actually make it harder for many recipients to leave welfare for work, because it cuts child care for working people, eliminates requirements for education and training, and gives states a perverse incentive to just cut people off welfare-whether or not they have moved into jobs.

To qualify as real welfare reform, moving people into the work force should be the centerpiece of Congressional legislation, not an afterthought. We need what I call a "pushpull" strategy. Everyone must start moving toward work from the first day they go on welfare. Sanctions must be swift and sure for anyone refusing to prepare for or look for work. If people need child care or job training in order to go to work, they should get help obtaining such services. And we should have tough national standards that make sure anyone who can work goes to work.

This is not a partisan issue. For years, Republicans and Democrats alike have agreed that the welfare system is broken because it does not demand or encourage work. We should not squander this historic opportunity to replace a system that fosters dependency with a system that instead does everything possible to place people in the work force and help them stay there.

This is a great challenge, but when states and the national government work together, we can succeed. In Florida, for example, a waiver granted by the Clinton administration is helping people get paychecks instead of welfare checks.

On a recent visit to Tallahassee, the president singled out one welfare recipient named Irene Marry, who is receiving the kind of training many mothers need to work and support their children. But, the truth is, there are many single mothers, in many states, now moving in the right direction.

Half the country is now on the road to ending welfare by promoting work and responsibility under waivers we have granted in the last two years.

In my view, these reforms are proof positive that Congress should build on-not repeal-the 1988 Family Support Act. This groundbreaking piece of legislation, passed by a bipartisan Congress, has allowed many states to make progress moving people into iobs. Simply giving the states more problems and less money will make it harder, not easier, for them to move welfare recipients to work.

States also need more flexibility - not less-to deal with the individual job readiness needs of teenagers, disabled parents, mothers caring for seriously ill children, and frightened young women who dropped out of high school and never went back. What they don't need is what many Democratic and Republican Senators recognize in the House bill's more punitive provisions: conservative micromanagement.

\section{Second, real welfare reform is tough on work, not tough on children.}

Over time, the House bill would deny cash assistance under the AFDC program to more than half the current caseload-almost three million mothers and six million children.

Over five years, the House bill cuts child nutrition by almost $\$ 6$ billion. It cuts protection services for abused, abandoned, and neglected children by more than $\$ 3$ billion. It denies both cash assistance and health coverage to hundreds of thousands of disabled children who need care.

These budget cuts have nothing to do with welfare reform.

Welfare reform is not about denying vulnerable children food and clothing; it is about giving them a shot at what every child needs: parents who can be inspirational role models.

Furthermore, we believe that teenagers and their small children, also singled out for cuts, should be helped into the work force as well. Instead of telling them to sink or swirn, true welfare reform should throw them a life preserver.

We believe-as many states do-that requiring teenage mothers to live at home, finish high school, and prepare to work is the only way to go. States like Ohio are finding great success by providing financial incentives to keep young mothers in school. This approach should be replicated, not banned.

We should be able to agree, without regard to party, on this basic principle: it is wrong to make small children pay the price for their parents' mistakes.

\section{Third, real welfare reform must bring Americans together, not drive them apart.}

The House debate on the issue set new lows in thetorical mud-wrestling, in which single mothers and their children 
were even referred to as animals: "wolves" and "alligators." Not only are such attacks unfair and uncharitable, they can prevent us from making headway on the real issues: work and responsibility.

We must do better at working together.

Fortunately, in one area, we have. The silver lining in the House welfare bill is that it beefs up child support enforcement, which is one of the reasons people go on welfare in the first place.

At first, the bill did not include any child support enforcement provisions. But President Clinton and members of both parties made the case that we must increase collections by telling deadbeat parents, "if you're not providing for your children, we'll garnish your wages, suspend your drivers' and professional licenses, track you across state lines, and, if necessary, make you work off what you owe."

Happily, the Republican leadership eventually listened to these tough-but-commonsense ideas-and their bill now demands responsibility from both parents. In fact, when the House finally voted on drivers' license revocation, it passed by a whopping 425 to 6 .

Such teamwork and consensus is possible on the Senate's broader welfare reform legislation, but only if work is the cornerstone of a real, bipartisan reform effort that puts long-term gains ahead of short-term politics.

Hopefully, all of us in Washington will look to Mark Twain for inspiration. "Always do right," he once wrote to young people in a Brooklyn church group in 1901. "This will gratify some people, and astonish the rest."

The truth is, we are standing at a crossroads in American history.

Ultimately, history will judge this debate by whether we moved millions of people into work, while protecting children and their futures. History will judge us by whether we were tough but not cruel, by whether we were bold but not extreme. History will judge us by whether we accepted the president's historic challenge to end welfare as we know it-and, together, got the job done. $\star$ 